clevelandfed.org/research/workpaper/index.cfm

Working Paper 9403

\title{
UNDERLYING DETERMINANTS OF CLOSED-BANK RESOLUTION COSTS
}

by William P. Osterberg and James B. Thomson

William P. Osterberg is an economist and James B. Thomson is an assistant vice president and economist at the Federal Reserve Bank of Cleveland. The authors thank Christopher Pike and Sandra Sterk for outstanding research support.

Working papers of the Federal Reserve Bank of Cleveland are preliminary materials circulated to stimulate discussion and critical comment. The views stated herein are those of the authors and not necessarily those of the Federal Reserve Bank of Cleveland or of the Board of Governors of the Federal Reserve System. 


\begin{abstract}
This paper looks at the underlying determinants of bank resolution costs. In the spirit of James (1991), resolution costs are modeled as functions of problem assets. However, we extend previous work by looking at more recent failures (from 1986 through 1992) and by extending our specification to include proxies for fraud, off-balance-sheet risk, brokered deposits, and both regional and size effects. Unlike James, we find no evidence that capital reflects net unbooked losses. On the other hand, we find roles for fraud, off-balance-sheet items, and both regional and size dummies. We also find evidence suggesting that regulators may have practiced forbearance.
\end{abstract}




\section{Introduction}

The last decade was marked by a record rate of post-Depression bank failures. From 1982 through the end of $1992,1,429$ banks were closed, accounting for 71 percent of all those closed since the inception of the Federal Deposit Insurance Corporation (FDIC) in 1934. More striking, however, were the record losses that were posted. The cost to the FDIC of resolving bank failures averaged 21 percent of total closed-bank assets from 1986 through 1992. By comparison, Benston et al. (1986) report that losses to depositors during the 193033 period of bank failures represented only about 0.81 percent of total failed-bank assets.

In response to the record number of bank closings and the skyrocketing costs of resolving nonviable banks, Congress enacted the Federal Deposit Insurance Corporation Improvement Act of 1991 (FDICIA). The main provisions of FDICIA sought to remove a certain degree of discretion from bank regulators in dealing with troubled depository institutions. The most notable of these provisions include prompt corrective action and limitations on the Federal Reserve's discount window. ${ }^{1}$ With these legal constraints on forbearance, Congress hoped to reduce the ultimate costs of resolving closed banks.

The degree to which FDICIA will meet its goals will critically depend on the correlation between book measures of net worth (the relevant measure of net worth for prompt corrective action) and economic net worth (the relevant measure for determining losses). Therefore, FDICIA-mandated closure rules will be effective only if they are binding on regulators, that is, if they force earlier closings than do unconstrained closure rules. This, of course, hinges on the lag between the realization of losses on assets and their recognition

\footnotetext{
${ }^{1}$ For a discussion of prompt corrective action, see Carnell (1992) and Pike and Thomson (1992). For a discussion of FDICIA's discount window provisions, see Todd (1993).
} 
by book-based regulatory accounting systems.

This paper looks at the underlying determinants of bank resolution costs and provides some evidence of a significant lag between the realization and recognition of losses on bank assets. Our approach is in the spirit of James (1991) and Bovenzi and Murton (1988) in that we model resolution costs as a function of problem assets, risky assets, and core deposits. We depart from those early studies in three ways. First, our research is more current: We look at FDIC commercial banks closed between 1986 and 1992, while James's sample includes banks closed from 1985 through the middle of 1988. Second, our measures of problem assets are taken from the Federal Financial Institutions Examination Council's (FFIEC) Quarterly Reports of Income and Condition (call reports). James uses confidential examination data. Finally, we extend our basic specification, which is analogous to that of James, to include proxies for fraud, off-balance-sheet risk, brokered deposits, and both regional and size effects. All of these variables are found to be significant determinants of closed-bank resolution costs. Several alternative specifications are rejected by the data.

\section{Three Faces of Closed-Bank Resolution Costs}

The ultimate cost of resolving an insolvent bank derives from three sources. First, there are the losses that reflect the underlying insolvency of the bank. These losses are the realization of the downside risk associated with a bank's investment and financing decisions. On an economist's extended balance sheet, these losses equal the negative market net worth of the firm (excluding the value of government guarantees). When looking at a historical cost accounting balance sheet, these losses will initially be unbooked losses. Net unbooked losses 
are likely to be correlated with the bank's capital, its problem assets, the risk structure of its balance sheet, and its off-balance-sheet activities.

The second component of resolution costs are the losses related to forbearance. ${ }^{2}$

Forbearance arises because, as Kane (1986) argues, bank regulators face constraints regarding information, funding, administrative and legal issues, and political considerations in dealing with insolvent banks. As a result, regulators adopt socially suboptimal closure rules.

Forbearance losses are the those incurred after the depository is no longer economically viable but before it is closed. ${ }^{3}$

Finally, there are the costs associated with receivership, including administrative and legal expenses. For example, expenses for the FDIC's division of liquidation averaged 8.3 percent of collections in 1991 (see the FDIC's 1991 Annual Report). ${ }^{4}$ Moreover, at the end of 1992, the FDIC's estimated contingent liability for unresolved legal cases was $\$ 404$ million. Costs of receivership also include losses that arise from the inefficient asset salvage operation of the receiver (see Kane [1990]).

In principle, it is difficult to separate resolution cost into its three components. To do so would require a model that predicts economic insolvency, a model of the regulatory

${ }^{2}$ Although the costs of forbearance have not been explicitly calculated for banks, DeGennaro and Thomson (1992) find that these costs were considerable for thrifts.

${ }^{3}$ Allen and Saunders (1993) model deposit insurance as a callable perpetual put option. The value of forbearance is the difference between the value of the call option under unconstrained regulatory closure rules and its value under constrained closure rules.

4 James (1991, table I) reports that administrative and legal expenses associated with bank closings were 9.96 percent of failed bank assets in 1985 and 1986. James' expense numbers are substantially higher than the FDIC's total administrative and legal expenses, which were 3.6 percent of failed bank assets for those years (see the FDIC's 1986 Annual Report). They are, however, similar to the FDIC's division of liquidation expenses as a percent of recoveries on receivership assets held by the FDIC for 1985 and 1986. 
closure rule, and clean estimates of the FDIC's marginal receivership cost associated with closing each bank. While Thomson's (1992) two-step model of the closure decision extends the bank failure literature by explicitly separating economic insolvency from the closure rule, there is considerable work left to be done on measuring and predicting insolvency and on modeling regulatory closure rules. ${ }^{5}$ Furthermore, little case-specific data on receivership costs is available, let alone the marginal receivership cost for each closed institution. Ultimately, therefore, we are left with estimating a resolution cost equation that includes all three types of resolution costs in the dependent variable.

\section{The Data and Empirical Model}

The sample includes all FDIC- and Bank Insurance Fund (BIF)- insured commercial banks that were closed or required FDIC financial assistance to remain open from January 1, 1986 through December 31, 1992. Quarterly balance sheet and income data for these banks are from the FFIEC's call reports from March 31, 1984 through December 31, 1992. Closure data, expected resolution cost (to the FDIC), and resolution type are from FDIC (1993).

We started with an empirical model similar to that in James (1991) by relating resolution costs (loss on assets in James) to sources of unbooked gains and losses on the bank's extended balance sheet. Unlike James, however, who had access to confidential data on asset quality and individual receivership cases, our proxies for unbooked gains and losses are constructed from balance sheet data reported on the quarterly call reports.

Table I contains a complete list of the proxy variables that we ultimately analyze in

\footnotetext{
${ }^{5}$ For a review of the bank failure literature, see Demirgüc-Kunt (1989).
} 
the study. RESCOST is the FDIC's estimated resolution cost as published by the FDIC (1993, appendix A). OREO, PD3090 (loans past due 30 days), and PDNA are initial proxy variables for asset quality. Given that the primary source of unbooked losses are losses on the asset portfolio, on-book problem assets should be a good proxy for the unbooked losses. CORE controls for the franchise (charter) value associated with core deposits (Keeley [1990]) and is a source of unbooked gains. Buser, Chen, and Kane (1981) argue that the FDIC will close banks in a manner that preserves the value of the charter in order to minimize its losses. ICORE is included in the model to control for the loss of the charter when the FDIC chooses liquidation as its resolution option. ${ }^{6}$

UNCOL is a proxy for problem assets not reported by the bank. As Bovenzi and Murton (1988) note, distressed banks have incentives to cover up the number of problem assets in their portfolio. One method for doing this is to book income on a nonperforming loan to prevent it from being classified as past due or nonaccruing. Therefore, UNCOL should be positively correlated with unbooked losses. Book equity plus reserves, CAP, represents the cushion between the value of assets and the promised payments to debt holders. NCRASST is included as a proxy for portfolio risk.

Initially, then, to be as close to James (1991) as possible, we estimate the following equation by weighted least squares, where the regressors are dated four to six months before the closure date:

\footnotetext{
${ }^{6}$ The FDIC has three basic choices in handling a troubled bank. First, it can liquidate the bank by selling its assets and paying off the deposits. Second, it can sell the closed bank to another financial institution. By selling the bank, the FDIC can preserve the value of its charter and thereby reduce the resolution costs by the amount of the premium the acquirer is willing to pay for this intangible asset. Finally, the FDIC can seek to preserve the charter's value through a direct capital infusion, known as open bank assistance. For a more thorough discussion of FDIC closed-bank resolution options, see Caliguire and Thomson (1987).
} 
(1) $\mathrm{RESCOST}=\alpha_{0}+\alpha_{1} \mathrm{OREO}+\alpha_{2} \mathrm{PD} 3090+\alpha_{3} \mathrm{PDNA}+\alpha_{4} \mathrm{CORE}$

$+\alpha_{5} \mathrm{ICORE}+\alpha_{6} \mathrm{UNCOL}+\alpha_{7} \mathrm{CAP}+\alpha_{8} \mathrm{NCRASST}+\varepsilon$.

We then test several alternative specifications relating to the inclusion of off-balancesheet items, insider loans, and brokered deposits. We also test for whether to lump together PD3090 and PDNA, OBSLNS and OBSOTHER. For the resulting specification, we then test for differences across size categories and regions. Regarding the size categories, we looked at differences across filer types (filer type is related to size) and across the size categories defined by the dummies DSZ1-DSZ6. Regarding regional effects, we examined differences across the regions defined by the regional dummies in the table and also tested for the inclusion of three variables capturing regional variation in banking conditions.

Next, we perform both stepwise and backwards regressions that consider the entire list of variables discussed above. Finally, we estimate the resulting specification for the five cases when the regressors are dated four to six months before closure, six to nine months before closure, 12 to 15 months before closure, 24 to 27 months before closure, and 36 to 39 months before closure.

The average resolution cost (RESCOST) for banks in the sample was $\$ 19.813$ million, or 21 percent of failed bank assets. Table II presents sample statistics for the regressors for the five fixed time intervals before closure. From table II, we see that the average size of banks closed was $\$ 141$ million in assets. Moreover, looking at TOTASS across the subsamples, we find that these banks shrank considerably in the year prior to closure. ${ }^{7} \mathrm{~A}$

\footnotetext{
${ }^{7}$ Data reported in the last two panels of table II do not include observations on some of the banks closed in 1986 and 1987. Therefore, while the data suggest that these banks may have shrunk for up to three years prior to closure, differences in the sample across time make it difficult to interpret differences in these means.
} 
similar pattern is exhibited by these banks' loan portfolios and their off-balance-sheet exposure. As one would expect, both capital and asset quality deteriorate in the last year before closure. Because balance-sheet items are unreliable immediately before closure, we confine our initial focus to the specification where the regressors are lagged four to six months prior to closure.

\section{Empirical Results}

Following James (1991), equation 2 is estimated using weighted least squares, where the observations are weighted by one over the square root of total assets, with all regressors dated four to six months prior to closure.

(2) RESCOST $=1033.395+0.522$ OREO + 0.511 PD3090 + 0.456 PDNA

$$
\begin{aligned}
& (380.512)^{\#}(0.060)^{\#} \quad(0.177)^{\#} . \quad(0.047) \\
& \text { - 0.019 CORE + 0.045 ICORE + 11.107 UNCOL - 1.315 CAP } \\
& \begin{array}{llll}
(0.008)^{\#} & (0.009)^{\#} & (0.934)^{\#} & (0.077)^{\#}
\end{array} \\
& +0.071 \mathrm{NCRASST}+\varepsilon \\
& (0.017)^{\#}
\end{aligned}
$$

Adj. $R^{2}: 0.798$.

No. of Obs.: 1121.

\# = Significant at the $1 \%$ confidence level.

Standard errors are in parentheses.

The results show that, on average, loans 30 days past due (PD3090) and loans that are past due 90 days or are nonaccruing (PDNA) increase resolution costs by 51 cents and 46 cents on the dollar, respectively. Also, as expected, holdings of other real estate owned (OREO) and other risky assets (NCRASST) raise the costs of resolution. Each dollar of core deposits reduces resolution costs by 1.9 cents. As in James, the positive and significant 
coefficient on ICORE suggests that the bank's charter value is lost when the institution is resolved through liquidation.

The coefficient on UNCOL is consistent with the interpretation that distressed banks use this item to hide growing asset-quality problems. Bovenzi and Murton (1988) note that income earned but not collected can arise from legitimate activities such as investments in real estate, where both the principal and interest are paid at maturity. However, we doubt that the magnitude of the estimated coefficient can be explained completely by such legitimate activities.

In James (1991), the coefficient on capital in the loss-on-assets equation is expected to be equal to zero if there are no unbooked gains or losses on assets. Here, on the other hand, since the dependent variable is resolution cost, we expect the coefficient on CAP to equal -1 in the absence of unbooked gains and losses. The estimated coefficient on CAP is both negative and significantly different from -1 . Thus, we are in agreement with James in finding evidence of net unbooked losses.

We then consider adding, separately, OBS, INSLNS, and BRKDEP. ${ }^{8}$ Standard F-tests imply that OBS and INSLNS $\left(\mathrm{F}_{2,1109}=202.420\right)$ belong in our specification, but do not imply adding BRKDEP once OBS and INSLNS $\left(\mathrm{F}_{1,1108}=1.713\right)$ are included. F-tests also suggest that we split OBS into its components, OBSLNS and OBSOTHER $\left(F_{1,1109}=83.458\right)$ and that we do not aggregate PD3090 and PDNA into a composite category $\left(F_{1,1109}=7.145\right)$.

(3) $\operatorname{RESCOST}=329.181+0.493$ OREO -0.462 PD3090 +0.807 PDNA

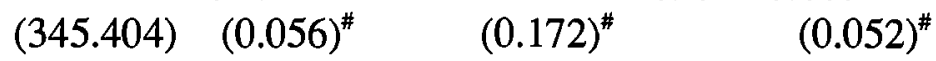

\footnotetext{
${ }^{8}$ Later on, when we consider regional effects, we include three additional non-dummy variables, BF (business failures), BFLIAB (liabilities of business failures), and PCI (an index of personal consumption) in stepwise and backwards regressions. None of these variables is included in the resulting specification.
} 
clevelandfed.org/research/workpaper/index.cfm

$$
\begin{aligned}
& \text { - 0.053 CORE + 0.046 ICORE + 5.735 UNCOL - 1.053 CAP } \\
& \begin{array}{llll}
(0.009)^{\#} \quad(0.008)^{\#} & (0.907)^{\#} & (0.073)^{\#}
\end{array} \\
& +0.248 \text { NCRASST }-0.186 \text { OBSLN }-0.054 \text { OBSOTHER }+2.783 \text { INSLNS } \\
& \begin{array}{llll}
(0.021)^{\#} & (0.016)^{\#} & (0.007)^{\#} & (0.267)^{\#}
\end{array} \\
& +\varepsilon
\end{aligned}
$$

Adj. $\mathrm{R}^{2}: 0.814$.

No. of Obs.: 1121.

\# = Significant at the $1 \%$ confidence level.

Standard errors are in parentheses.

In equation (3), the coefficients on both categories of off-balance-sheet items are negative and significant. In the case of off-balance-sheet loan items (OBSLN), such as loan commitments and letters of credit, we can interpret the negative coefficient as indicating market discipline. For OBSOTHER, a negative coefficient is consistent with derivative securities being used to hedge against on-balance-sheet risk. ${ }^{9}$

The coefficient on loans to insiders (INSLNS) is expected to be negative if the bank relaxed credit standards in making such loans. However, under this explanation we would not expect the coefficient to exceed one, as is the case here. This is consistent with Thomson's $(1991,1992)$ interpretation of INSLNS as a proxy for fraud. ${ }^{10}$

The augmented specification (3) is next estimated separately by filer type, referring to the FFIEC form submitted. The four categories are 1) banks with domestic and foreign offices, 2) banks with only domestic offices and total assets no more than $\$ 100$ million, 3) banks with only domestic offices and total assets between $\$ 100$ million and $\$ 300$ million, 4)

\footnotetext{
${ }^{9}$ See Avery and Berger (1991), Boot and Thakor (1991), and Koppenhaver and Stover (1991).

${ }^{10}$ Graham and Horner (1988) find that fraud was a significant factor in the failure of 35 percent of national banks closed between 1979 and 1987.
} 
banks with only domestic offices and total assets over $\$ 300$ million. Using another F-test, we reject the restriction that the coefficients are equal across filer types $\left(F_{36,1073}=16.434\right)$. Since filer type does not exactly correspond to size, we also estimate the same specification for each of the dummy variable categories, DSZ1-DSZ6. We reject the restriction that the coefficients are equal across these size categories $\left(\mathrm{F}_{33,110}=4.401\right) .{ }^{11}$ We then estimate the same specification for all banks, but with the size dummies included as regressors. To avoid the dummy variable trap, we must exclude either the intercept or one of the dummies. ${ }^{12}$

We follow a similar procedure regarding regional effects. First, we estimate (3) for each region, where each region is chosen by the dummy variables, DUMSE, DUMHP, DUMSW, DUMWE, DUMMW, and DUMNE. We reject the restriction that the coefficients are equal across regions $\left(F_{60,1109}=16.486\right) .{ }^{13}$ Then we estimate the same specification with five of the regional dummies (excluding DUMNE) on the right-hand side with an intercept. It is well known that such a resulting specification may be sensitive to the order in which variables are entered, so we next analyze the total list of variables using both stepwise and backwards regression. At this point, we also include in the list three variables that may capture variation in regional economic conditions: BF, BFLIAB, and PCI. Because the backwards regression procedure starts with the full list of potential regressors, we must leave out one of the size dummies (DSZ1) and one of the regional dummies (DUMNE). At this

\footnotetext{
${ }^{11}$ This test statistic was calculated for the restriction that the coefficients are equal across the four categories: DSZ1=1, DSZ2=1, DSZ3=1, and all other banks.

${ }^{12}$ Because the size category for DSZ6 includes only five banks, including that dummy implies almost perfect collinearity. Also, OBSOTHER is not reported for the smallest banks (DSZ1=1).

${ }^{13}$ The specification is different for DUMMW=1 because OBSOTHER is missing.
} 
point, we also examine the collinearity diagnostics suggested by Belsley, Kuh, and Welsch (1980). We deem that a component induces harmful collinearity when its condition index is over 30. We also deem that the standard error of a particular coefficient estimate has been unacceptably degraded if a high proportion of its variance is associated with a component with a high condition index.

The results from the stepwise and backwards regressions are broadly similar. All of the non-dummy variables belong, with the exception of the three regional conditions measures (BF, BFLIAB, and PCI) and PD3090. Also, BRKDEP now appears in the final specification even though our original test implied its exclusion. There are differences between the two procedures regarding the regional and size dummies. With the backwards regressions, all of the size and regional dummies are kept, other than those that had to be excluded (DSZ1 and DUMNE) to avoid the dummy variable trap. The collinearity diagnostics for each procedure did indicate that the final component induced harmful collinearity. However, as all $\mathrm{t}$-statistics implied significance at the 1 percent level, we did not redo the backwards and stepwise procedures with a reduced list of regressors. The final specification of the model as indicated by the stepwise procedure (using data for the four- to six-month time horizon) is

(4) $\mathrm{RESCOST}=\alpha_{0}+\alpha_{1} \mathrm{UNCOL}+\alpha_{2} \mathrm{CAP}+\alpha_{3} \mathrm{PDNA}+\alpha_{4} \mathrm{OREO}+\alpha_{5}$ INSLNS

$$
\begin{aligned}
& +\alpha_{6} \text { NCRASST }+\alpha_{7} \text { OBSLN }+\alpha_{8} \text { OBSOTHER }+\alpha_{9} \text { CORE }+\alpha_{10} \text { ICORE } \\
& +\alpha_{11} \text { DSZ6 }+\alpha_{12} \text { DSZ1 }+\alpha_{13} \text { DSZ2 }+\alpha_{14} \text { DSZ3 }+\alpha_{15} \text { BRKDEP } \\
& +\alpha_{16} \text { DUMNE }+\alpha_{17} \text { DSZ4 }+\alpha_{18} \text { DUMSW }+\varepsilon .
\end{aligned}
$$

In Table III, we report the weighted least squares results for equation (4) when that 
specification is run for varying horizons (the regressors are lagged in varying lengths).

Overall, the results for the four- to six-month time-to-closure horizon are consistent with those for specifications (1) and (2). The coefficients on UNCOL, PDNA, OREO, INSLNS, ICORE, and NCRASST are positive and significant, while the coefficients on CAP, CORE, OBSLN, and OBSOTHER are negative and significant. Moreover, while there are some minor differences in terms of the size of the coefficients across equations, qualitatively the results are the same as those for specifications (1) and (2).

The coefficient on brokered deposits is negative and significant, suggesting that banks' reliance on money markets for funding reduces ultimate resolution costs. One could interpret this result as a sign of market discipline. Another possible conclusion is that troubled banks that are heavily reliant on brokered funds are more likely to be subject to prompt closure. This interpretation is consistent with Thomson's (1992) model of the regulatory closure decision.

The coefficients on the size dummies are consistent with a direct relationship between the fixed costs associated with resolving a closed bank and the bank's asset size. Finally, the positive and significant coefficients on DUMNE and DUMSW indicate that the depressed economies in the Northeast and Southwest contributed significantly to the costs of resolving failed banks in those regions.

Interpretation of the results for equation (4) estimated using data more than six months before closing is not as straightforward as that for the four- to six-month results. However, a cursory look at each coefficient across the five different subsamples indicates regulatory forbearance. Our ability to explain expected resolution costs at time of closure 
using data up to 39 months before the closure date suggests that banks closed between 1986 and 1992 were insolvent long before their doors were shut. Moreover, the pattern of individual regression coefficients across time-to-closure subsamples indicates an increase in unbooked losses, the further one gets from the closure date. For example, the coefficients on PDNA and OREO rise monotonically with the time-to-closure horizon.

\section{Conclusion}

In this paper, we have extended previous examinations of the determinants of bank failure-resolution costs. We examine the balance-sheet determinants of the FDIC's estimated cost of resolution and confirm most of the findings of James (1991), who looked at loss on assets and used confidential examiner reports. However, unlike James, we find no evidence that our capital variable reflects net unbooked losses in addition to the other variables included in the analysis. ${ }^{14}$ In addition, we find a role for insider loans, off-balance-sheet items, and both regional and size dummies.

When we extend the interval between the observation of the banks' balance sheets and the time of closure, we find that the balance-sheet data can still explain a high percentage of the resolution costs. This suggests that regulators may have practiced forbearance.

Our research can be extended in several directions. First, modeling the regulators' closure decisions by adding an equation to predict closure would allow us to focus more carefully on the role of forbearance in explaining resolution costs. Second, examining the

\footnotetext{
${ }^{14}$ We do find evidence of unbooked losses in our capital variable when we estimate our base model (equation [1]), which was motivated by James (1991). However, we cannot reject the hypothesis that the coefficient on the capital variable equals - 1 once off-balance-sheet items and insider loans are included in the model (equations [3] and [4]).
} 
clevelandfed.org/research/workpaper/index.cfm

determinants of resolution type would further allow us to disentangle the influences of balance-sheet items and regulatory response. These changes would also permit further identification of the roles of insider loans and off-balance-sheet items. 


\section{References}

Allen, L., and A. Saunders, 1993, "Forbearance and the Valuation of Deposit Insurance as a Callable Perpetual Put," Journal of Banking and Finance 16 (June), 629-643.

Avery, R. B., and A. N. Berger, 1991, "Loan Commitments and Bank Risk Exposure," Journal of Banking and Finance 15 (September), 173-192.

Barth, J. R., P. F. Bartholomew, and M. G. Bradley, 1990, "Determinants of Thrift Institution Resolution Costs," Journal of Finance 45 (July), 731-754.

Belsley, D., E. Kuh, and R. Welsch, 1980, Regression Diagnostics, New York: John Wiley \& Sons.

Benston, G. J., R. A. Eisenbeis, P. M. Horvitz, E. J. Kane, and G. G. Kaufman, 1986, Perspectives on Safe and Sound Banking: Past, Present, and Future. Cambridge, MA: MIT Press.

Blalock, J. B., T. J. Curry, and P. J. Elmer, 1991, "Resolution Costs of Thrift Failures," FDIC Banking Review 4 (Spring/Summer), 15-26.

Boot, A. W. A., and A. V. Thakor, 1991, "Off-Balance-Sheet Liabilities, Deposit Insurance, and Capital Requirements," Journal of Banking and Finance 15 (September), 825-846.

Bovenzi, J. F., and A. J. Murton, 1988, "Resolution Costs of Bank Failures," FDIC Banking Review 1 (Fall), 1-11.

Brown, R. A., and S. Epstein, 1992, "Resolution Costs of Bank Failures: An Update of the Historical Loss Model," FDIC Banking Review 5 (Spring/Summer), 1-16.

Buser, S. A., A. H. Chen, and E. J. Kane, 1981, "Federal Deposit Insurance, Regulatory Policy, and Optimal Bank Capital," Journal of Finance 36 (September), 775-787.

Caliguire, D. B., and J. B. Thomson, 1987, "FDIC Policies for Dealing with Failed and Troubled Institutions," Economic Commentary, Federal Reserve Bank of Cleveland, (October 1).

Carnell, R. S., 1992, "A Partial Antidote to Perverse Incentives: The FDIC Improvement Act of 1991," Conference on Rebuilding Public Confidence Through Financial Reform, The Ohio State University.

DeGennaro, R. P., and J. B. Thomson, 1992, "Capital Forbearance and Thrifts: An Ex Post Examination of Regulatory Gambling," Working Paper 9209, Federal Reserve Bank of Cleveland (September). 
Demirgüç-Kunt, A., 1989, "Deposit-Institution Failures: A Review of the Empirical Literature," Economic Review, Federal Reserve Bank of Cleveland (Quarter 4), 2-18.

Federal Deposit Insurance Corporation, 1993, "Failed Bank Cost Analysis: 1986-1992," Washington, D.C. (FDIC).

Graham, F. C., and J. E. Horner, 1988, "Bank Failure: An Evaluation of the Factors Contributing to the Failure of National Banks," Proceedings from a Conference on Bank Structure and Competition, Federal Reserve Bank of Chicago (May), 405-435.

James, C., 1991, "The Losses Realized in Bank Failures," Journal of Finance 46 (September), 1223-1242.

Kane, E. J., 1986, "Appearance and Reality in Deposit Insurance Reform," Journal of Banking and Finance 10, 175-188.

Kane, E. J., 1990, "Principal-Agent Problems in S\&L Salvage, Journal of Finance 45 (July), 755-764.

Keeley, M. C., 1990, "Deposit Insurance, Risk, and Market Power in Banking," American Economic Review 80 (December), 1183-1200.

Koppenhaver, G. D., and R. D. Stover, 1991, "Standby Letters of Credit and Bank Capital: Evidence of Market Discipline," Proceedings from a Conference on Bank Structure and Competition, Federal Reserve Bank of Chicago (May), 373-394.

Pike, C. J., and J. B. Thomson, 1992,"FDICIA's Prompt Corrective Action Provisions," Economic Commentary, Federal Reserve Bank of Cleveland (September 1).

Randall, R. E., 1993, "Lessons from New England Bank Failures," New England Economic Review (May/June), 13-50.

Thomson, J. B., 1991, "Predicting Bank Failures in the 1980s," Economic Review, Federal Reserve Bank of Cleveland (Quarter 1), 9-20.

Thomson, J. B., 1992, "Modeling the Bank Regulator's Closure Option: A Two-Step Logit Regression Approach," Journal of Financial Services Research 6, 5-23.

Todd, W. F., 1993, "Discount Window Provisions of the Federal Deposit Insurance Corporation Improvement Act of 1991," Banking Policy Report (March 1). 
Table I: Variable Definitions

\begin{tabular}{|c|c|c|}
\hline VARIABLE & $\mathrm{SIGN}^{\mathrm{a}}$ & DESCRIPTION \\
\hline RESCOST & NA & $\begin{array}{l}\text { The estimated cost to the FDIC of resolving the bank, as reported in FDIC } \\
(1993 \text {, appendix A). }\end{array}$ \\
\hline UNCOL & + & Interest income earned on loans that is uncollected. \\
\hline CAP & - & Equity capital plus the loan loss reserve and allocated risk transfer reserve. \\
\hline PDNA & + & Loans that are 90 days past due but still accruing, and nonaccrual loans. \\
\hline OREO & + & Other real estate owned. \\
\hline INSLNS & + & Loans to insiders. \\
\hline NCRASST & + & $\begin{array}{l}\text { Risky assets that are not included in the totals for OREO, PD30 (loans that } \\
\text { are } 30 \text { days past due but still accruing), PDNA, or loans to insiders. }\end{array}$ \\
\hline OBSLN & $?$ & $\begin{array}{l}\text { The total notional value of loan commitments, loan sales, and standby } \\
\text { letters of credit reported. }\end{array}$ \\
\hline OBSOTHER & ? & The total notional value of other off-balance-sheet items reported by banks. \\
\hline CORE & - & Core deposits: measured as domestic deposits under $\$ 100,000$. \\
\hline ICORE & + & Equals CORE if the bank was resolved via a payout. \\
\hline TOTASS & NA & Total on-balance-sheet assets. \\
\hline \multicolumn{3}{|c|}{ Size Dummy Variables } \\
\hline DSZ1 & $?$ & $=1$ if TOTASS $\leq \$ 50$ million, 0 otherwise; \\
\hline DSZ2 & ? & $=1$ if $\$ 50$ million $<$ TOTASS $\leq \$ 100$ million, 0 otherwise; \\
\hline DSZ3 & ? & $=1$ if $\$ 100$ million $<$ TOTASS $\leq \$ 500$ million, 0 otherwise; \\
\hline DSZ4 & $?$ & $=1$ if $\$ 500$ million $<$ TOTASS $\leq \$ 1$ billion, 0 otherwise; \\
\hline DSZ5 & $?$ & $=1$ if $\$ 1$ billion $<$ TOTASS $\leq \$ 5$ billion, 0 otherwise; \\
\hline DSZ6 & ? & $=1$ if $\$ 5$ billion < TOTASS, 0 otherwise. \\
\hline \multicolumn{3}{|c|}{ Regional Dummy Variables (defined by Federal Reserve District) } \\
\hline DUMSE & $?$ & $=1$ if the bank is in the Richmond or Atlanta Fed District; \\
\hline DUMMW & $?$ & $=1$ if the bank is in the Cleveland, Chicago, or St. Louis Fed District; \\
\hline DUMSW & ? & $=1$ if the bank is in the Dallas Fed District; \\
\hline DUMHP & $?$ & $=1$ if the bank is in the Minneapolis or Kansas City Fed District; \\
\hline DUMWE & $?$ & $=1$ if the bank is in the San Francisco Fed District; \\
\hline DUMNE & ? & $=1$ if the bank is in the Boston, New York, or Philadelphia Fed District. \\
\hline
\end{tabular}

Notes: a. Expected sign for the regression coefficient in equations (1), (2), or (3).

Source: Authors. 
Table III: WLS RESULTS FOR EQUATION $3^{a}$

X Months < Call Report < Y Months before Failure

\begin{tabular}{|c|c|c|c|c|c|}
\hline Regressor & 4 to 6 & 6 to 9 & 12 to 15 & 24 to 27 & 36 to 39 \\
\hline$\alpha_{0}$ & $\begin{array}{l}69842 \\
(13394)^{\#, b}\end{array}$ & $\begin{array}{l}81400 \\
(12977)^{*}\end{array}$ & $\begin{array}{l}134598 \\
(13996)^{*}\end{array}$ & $\begin{array}{l}18846 \\
(14748)^{\#}\end{array}$ & $\begin{array}{l}29201 \\
(16965)^{\#}\end{array}$ \\
\hline UNCOL & $\begin{array}{l}4.3759 \\
(0.8926)^{\#}\end{array}$ & $\begin{array}{l}3.2879 \\
(0.8550)^{\#}\end{array}$ & $\begin{array}{l}2.9665 \\
(0.8109)^{\#}\end{array}$ & $\begin{array}{l}2.1219 \\
(0.8814)^{\#}\end{array}$ & $\begin{array}{l}2.0795 \\
(1.1428)^{\#}\end{array}$ \\
\hline CAP & $\begin{array}{l}-1.1649 \\
(0.0719)^{\#}\end{array}$ & $\begin{array}{l}-1.1067 \\
(0.0894)^{\#}\end{array}$ & $\begin{array}{l}-1.0456 \\
(0.1217)^{\#}\end{array}$ & $\begin{array}{l}-0.2782 \\
(0.1982)^{\#}\end{array}$ & $\begin{array}{l}-0.7490 \\
(0.2495)^{\#}\end{array}$ \\
\hline PDNA & $\begin{array}{l}0.7864 \\
(0.0492)^{\#}\end{array}$ & $\begin{array}{l}0.9395 \\
(0.0499)^{\#}\end{array}$ & $\begin{array}{l}1.3929 \\
(0.0896)^{\#}\end{array}$ & $\begin{array}{l}1.0126 \\
(0.1368)^{\#}\end{array}$ & $\begin{array}{l}1.2798 \\
(0.2262)^{\#}\end{array}$ \\
\hline OREO & $\begin{array}{l}0.4530 \\
(0.0559)^{\#}\end{array}$ & $\begin{array}{l}0.4796 \\
(0.0593)^{*}\end{array}$ & $\begin{array}{l}0.6890 \\
(0.0726)^{\#}\end{array}$ & $\begin{array}{l}0.8128 \\
(0.0815)^{\#}\end{array}$ & $\begin{array}{l}0.9358 \\
(0.1589)^{\#}\end{array}$ \\
\hline INSLNS & $\begin{array}{l}1.7751 \\
(0.2763)^{\#}\end{array}$ & $\begin{array}{l}1.3290 \\
(0.2858)^{\#}\end{array}$ & $\begin{array}{l}0.0115 \\
(0.0913)^{\#}\end{array}$ & $\begin{array}{l}1.1319 \\
(0.2402)^{\#}\end{array}$ & $\begin{array}{l}1.1111 \\
(0.1938)^{\#}\end{array}$ \\
\hline NCRASST & $\begin{array}{l}0.2019 \\
(0.0201)^{\#}\end{array}$ & $\begin{array}{l}0.2581 \\
(0.0227)^{\#}\end{array}$ & $\begin{array}{l}0.3009 \\
(0.0255)^{\#}\end{array}$ & $\begin{array}{l}0.1019 \\
(0.0303)^{\#}\end{array}$ & $\begin{array}{l}0.1311 \\
(0.0265)^{\#}\end{array}$ \\
\hline OBSLN & $\begin{array}{l}-0.1576 \\
(0.0160)^{\#}\end{array}$ & $\begin{array}{l}-0.1788 \\
(0.0209)^{\#}\end{array}$ & $\begin{array}{l}-0.1773 \\
(0.0196)^{\#}\end{array}$ & $\begin{array}{l}0.1908 \\
(0.0222)^{\#}\end{array}$ & $\begin{array}{l}0.2127 \\
(0.0186)^{\#}\end{array}$ \\
\hline OBSOTHER & $\begin{array}{l}-0.0384 \\
(0.0074)^{\#}\end{array}$ & $\begin{array}{l}-0.0311 \\
(0.0053)^{\#}\end{array}$ & $\begin{array}{l}-0.0708 \\
(0.0037)^{\#}\end{array}$ & $\begin{array}{l}-0.1004 \\
(0.0070)^{\#}\end{array}$ & $\begin{array}{l}-0.1803 \\
(0.0149)^{\#}\end{array}$ \\
\hline CORE & $\begin{array}{l}-0.0879 \\
(0.0097)^{\#}\end{array}$ & $\begin{array}{l}-0.1339 \\
(0.0103)^{\#}\end{array}$ & $\begin{array}{l}-0.2333 \\
(0.0116)^{\#}\end{array}$ & $\begin{array}{l}-0.1036 \\
(0.0187)^{\#}\end{array}$ & $\begin{array}{l}-0.0928 \\
(0.0179)^{\#}\end{array}$ \\
\hline ICORE & $\begin{array}{l}0.0618 \\
(0.0088)^{\#}\end{array}$ & $\begin{array}{l}0.0412 \\
(0.0087)^{\#}\end{array}$ & $\begin{array}{l}0.0521 \\
(0.0096)^{\#}\end{array}$ & $\begin{array}{l}-0.0511 \\
(0.0101)^{*}\end{array}$ & $\begin{array}{l}-0.0485 \\
(0.0116)^{\#}\end{array}$ \\
\hline DSZ6 & $\begin{array}{l}466982 \\
(51538)^{*}\end{array}$ & $\begin{array}{l}489923 \\
(53678)^{*}\end{array}$ & $\begin{array}{l}586938 \\
(51844)^{\#}\end{array}$ & $\begin{array}{l}-314809 \\
(50229)^{\#}\end{array}$ & $\begin{array}{l}-409859 \\
(58407)^{\#}\end{array}$ \\
\hline
\end{tabular}


Table III (continued): WLS RESULTS FOR EQUATION $3^{\text {a }}$

\begin{tabular}{|c|c|c|c|c|c|}
\hline \multirow[b]{2}{*}{ Regressor } & \multicolumn{5}{|c|}{ X Months $<$ Call Report $<$ Y Months Before Failure } \\
\hline & 4 to 6 & 6 to 9 & 12 to 15 & 24 to 27 & 36 to 39 \\
\hline DSZ1 & $\begin{array}{l}-69250 \\
(13290)^{\#}\end{array}$ & $\begin{array}{l}81400 \\
(12977)^{\#}\end{array}$ & $\begin{array}{l}130498 \\
(13996)^{\#}\end{array}$ & $\begin{array}{l}-16740 \\
(14641) \#\end{array}$ & $\begin{array}{l}-26551 \\
(16818)^{\#}\end{array}$ \\
\hline DSZ2 & $\begin{array}{l}-65659 \\
(13039)^{\#}\end{array}$ & $\begin{array}{l}-75640 \\
(12649)^{\#}\end{array}$ & $\begin{array}{l}-122915 \\
(13611)^{\#}\end{array}$ & $\begin{array}{l}-11992 \\
(14449) \#\end{array}$ & $\begin{array}{l}-21597 \\
(16556)^{\#}\end{array}$ \\
\hline DSZ3 & $\begin{array}{l}-56594 \\
(12484)^{\#}\end{array}$ & $\begin{array}{l}-66183 \\
(12109)^{\#}\end{array}$ & $\begin{array}{l}-106014 \\
(13092)^{\#}\end{array}$ & $\begin{array}{l}1067.4296 \\
(13918) \#\end{array}$ & $\begin{array}{l}-9081.2825 \\
(15949)^{\#}\end{array}$ \\
\hline BRKDEP & $\begin{array}{l}-0.0949 \\
(0.0336)^{\#}\end{array}$ & $\begin{array}{l}-0.0713 \\
(0.0337)^{\#}\end{array}$ & $\begin{array}{l}-0.2199 \\
(0.0485)^{\#}\end{array}$ & $\begin{array}{l}-0.3452 \\
(0.0967)^{\#}\end{array}$ & $\begin{array}{l}-0.2030 \\
(0.0819)^{\#}\end{array}$ \\
\hline DUMNE & $\begin{array}{l}5856.8943 \\
(1692.769)^{\#}\end{array}$ & $\begin{array}{l}6777.7280 \\
(1714.668)^{\#}\end{array}$ & $\begin{array}{l}10253 \\
(1792.589)^{\#}\end{array}$ & $\begin{array}{l}14426 \\
(1990.963)^{\#}\end{array}$ & $\begin{array}{c}19096 \\
(2137.5231)^{\#}\end{array}$ \\
\hline DSZ4 & $\begin{array}{l}-34555 \\
(11588)^{\#}\end{array}$ & $\begin{array}{l}-40628 \\
(11289)^{\#}\end{array}$ & $\begin{array}{l}-73158 \\
(12207)^{\#}\end{array}$ & $\begin{array}{l}-8425.7253 \\
(13245)^{\#}\end{array}$ & $\begin{array}{l}3374.454 \\
(14747)^{\#}\end{array}$ \\
\hline DUMSW & $\begin{array}{l}1345.0192 \\
(593.1150)^{\#}\end{array}$ & $\begin{array}{l}1241.1026 \\
(608.253)^{\#}\end{array}$ & $\begin{array}{l}1884.2187 \\
(641.4230)^{\#}\end{array}$ & $\begin{array}{l}956.4019 \\
(755.178)^{\#}\end{array}$ & $\begin{array}{l}1319.4845 \\
(878.5572)^{\#}\end{array}$ \\
\hline
\end{tabular}

Notes: Sample includes all FDIC-insured banks that failed from January 1986 through December 1992. Data are from the FFIEC Quarterly Reports of Condition and Income from January 1984 through December 1992 and from the FDIC (1993).

a) Observations are weighted by one over the square root of total assets.

b) Standard errors are in parentheses.

\#: Significantly different from zero at the 1 percent confidence level.

Source: Authors. 